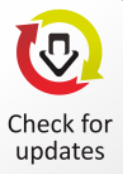

updates
Article Type: Research Paper

\section{The Impact of Corporate Governance on Customer Satisfaction and Loyalty of Islamic Insurance Company in Indonesia}

\author{
Peni Nugraheni ${ }^{1 *}$ and Lia Fauziah ${ }^{1}$
}

\begin{abstract}
The implementation of corporate governance in managing Islamic insurance companies hopefully can support the performance of companies to provide the best services for consumers based on Islamic principles. Good performance related to transparency, independence, accountability, responsibility, fairness, and sharia compliance are expected to increase the trust of potential customers of Islamic insurance. This study aims to examine the impact of corporate governance on customer satisfaction and customer loyalty in Islamic insurance companies in Indonesia. A purposive sampling technique used for this research. Questionnaires developed as primary data for Islamic insurance customers, this study found that corporate governance positively influences customer satisfaction and customer loyalty. Another result reveals that customer satisfaction positively influences customer loyalty. This study recommends the strengthening of corporate governance implementation to enhance the attractiveness of Islamic insurance company and give impacts on customer satisfaction and customer loyalty.
\end{abstract}

KEYWORDS: islamic insurance; corporate governance; customer satisfaction; customer loyalty

Nugraheni, P. \& Fauziah, L. (2019). The Impact of Corporate Governance on Customer Satisfaction and Loyalty of Islamic Insurance Company in Indonesia. Journal of Accounting and Investment, 20(2), 114-128.

\section{ARTICLE HISTORY}

Received:

21 December 2018

Reviewed:

4 April 2019

Revised:

13 April 2019

Accepted:

14 April 2019

\section{Introduction}

The importance of insurance role in economic growth encourages an increase in the number of Islamic insurance companies. Islamic insurance (takaful) companies have an important role for community to be one of Islamic financial instruments that stands for income distribution and social-oriented activities (Zairi, 2014). Indonesia has a great potential in takaful development due to the high population and market expansion acceleration of middle-class community (Karim Consulting, 2017). Based on data from Financial Service Authority of Indonesia (OJK, 2018), in the year of 2017, there are 12 Takaful insurance companies and 48 Sharia business units (SBU) in Indonesia with the total of assets reaching 35,249 billion rupiah. However, until the first quarter of 2017, the market share of Takaful is only around $3.47 \%$ if being compared with the market share of conventional insurance. 
Conventional insurance is not suitable for Muslim because of some reasons, (Rahim \& Amin, 2011), first, the contract between the insurer and the insured contains uncertainty (gharar), second, the company may do investment involving the element of riba and third, the existence of gharar will lead to maysir or gambling. However, Muslim acceptance of the existence of Islamic insurance is still questionable (Rahim \& Amin, 2011). Redhika and Mahalli (2014) mention that there are factors that become challenges regarding low market penetration of takaful, such as lack of promotion and market education, limited products and services, lack of product innovation, and community's doubt whether Takaful's products adhere to Sharia principles.

According to Ali (2011), the needs of transparency in managing the Takaful's activities such as tabarru fund, supervising the management of tabarru fund and improvements the human resources are the challenges in this industry. In expanding the market share, takaful companies need to get trust from their potential customers. In the other side, maintaining the trust and satisfaction of the existing customers are also important because this group sometimes recommends takaful to the others. Companies can do some strategies such as establishing good performance, good corporate governance, accountability, and responsibility, contributing to society and performing sharia compliance. The insurance industry is required to have good corporate governance to increase the trust of policyholders in particular, and stakeholders in general (KNKG, 2010). Corporate governance becomes one of the challenges faced by the takaful industry in developing its market, in addition to its sharia compliance and the lack of public awareness (Jaffer et al., 2010).

Implementation of corporate governance (CG) principles enhances the performance of the industry to provide the best product and service for customers in accordance with the sharia principles. This is expected to create customer satisfaction and maintain consumer loyalty and even increase the market of takaful industry. Tahir and Brimble (2011) find that the investment behavior of Muslims depends on their religiosity level. Religious Muslim investors will be influenced by Islamic principle in choosing financial investment; otherwise, non-religious Muslim prefer to consider the profit and sustainable investment regarding asset allocation. However, takaful industry does not only rely on its sharia-compliance to attract the intention of customer to participate in takaful; but also, good performance can strengthen the position of takaful companies to compete with the conventional counterpart.

Many previous researchers studied regarding the relationship between CG and financial performance or corporate social responsibility. Examining the relationship between CG and customer also interesting because CG plays significant role in improving the relationship between management and stakeholders (i.e., customers) that lead to better performance (Al-Qudah, 2012). According to Al-Qudah (2012), the main purpose of the company is getting profit, and in normal business activities, the company receives profit from the sale of good and services. It tells the importance of customer's role in the company's sustainability. El-Junusi (2012) and Wardayati (2011) find that sharia governance influenced company's reputation and customer's trust in Indonesian Islamic banking. Janjua and Akmal (2014) compare the customer satisfaction for the quality 
services of conventional insurance and Islamic insurance in Pakistan. The results indicate that there are (1) significant gap between expectation and perception of overall insurance industry, and (2) significant improvement on service quality in conventional and Islamic insurance. Mohsan et al. (2011) collect data from customers of banking industry in Pakistan and found that customer satisfaction was positively correlated with customer loyalty.

There is still lack of research about the link between corporate governance, customer satisfaction, and customer loyalty in takaful industry in Indonesia. Many researchers examine those relationships just limited in the banking industry or manufacturing and services companies. This study expects to extend the existing of literature by examining the influence of corporate governance on customer satisfaction and customer loyalty, specifically in takaful companies in Indonesia. There are several reasons for the importance of research on takaful. First, insurance has a significant role in a country's economy, and therefore, the growth of this industry is important to be supported. Second, one way to maintain the existence of the takaful industry is to expand the market and maintain customer satisfaction and loyalty in this industry. Takaful market in Indonesia is enormous, considering that Muslims become the majority in this country. Third, the implementation of good corporate governance that has many benefits can be used as a tool to increase the market share of this industry.

The significance of this study is to contribute to the management of Islamic insurance companies to improve their customer satisfaction and customer loyalty. The result of this study will encourage companies to protect the customers' interest through strong corporate governance. Also, the research can be a reference for the enrichment of knowledge in Islamic insurance companies.

\section{Literature Review and Hypotheses Development}

\section{Corporate Governance in Islamic Insurance Industry}

According to Hasan (2009), corporate governance (CG) refers to "....a system by which companies are directed and controlled with a purpose to meet the corporation's objective by protecting all the stakeholders' interest and right" (p.278). Islamic Financial Institutions (IFIs) are also directed to implement CG in order to create well-managed companies. In the area of the financial services sector, CG has a purpose to ensure fairness to all stakeholders through greater transparency and accountability (Hasan, 2009). Therefore, it becomes a tool for companies to demonstrate good governance to enhance stakeholder trust, including in the insurance industry. Specifically, KNKG (2010) states that the implementation of good corporate governance (GCG) in the insurance industry is to obtain the business continuity of the company based on the principle of transparency, accountability, responsibility, independence and fairness, and equality. Meanwhile, the regulation of Otoritas Jasa Keuangan (OJK/Financial Service Authority) Number 73/POJK.05/2016 Concerning to Good Corporate Governance for Insurance Company mentions that the implementation of GCG aims to: (1) optimize the value of 
insurance companies for stakeholders especially the policyholder, the insured, and the participant, (2) improve the management of the insurance company professionally, effectively and efficiently; (3) improve the compliance of the insurance company's organ and sharia supervisory board and its subordinates in making decisions and taking actions based on high ethics, compliance with laws and social responsibility awareness, (4) realize insurance company which healthy, reliable, trustworthy, and competitive; and (5) increase the contribution of insurance companies in the national economy.

The regulation also states the GCG Principles consist of (1) transparency, is openness in the decision-making process and disclosure and provision of relevant and easily accessible information, (2) accountability, is the clarity of functions and the responsibility implementation of the insurance company's organs so that the performance of the insurance company can be transparent, reasonable, effective and efficient; (3) responsibility, is the compliance of the insurance company's management with the provisions of legislation, ethical values and standards, principles and practices of the implementation of a health insurance business; (4) independence, refers to management of insurance company that is independent, professional, free from conflict of interest and free from the influence or pressure of any party, (5) fairness, is equality, balance and justice in fulfilling the rights of stakeholders.

These corporate governance principles should be applied in an Islamic insurance company. In addition, to meet the five principles above, there is also one more principle that is conformity with the sharia principles. This principle is handled by Sharia supervisory boards to oversee that corporate activities are in accordance with sharia principles. Kamarulzaman and Madun (2013) state that one of the challenges faced by IFIs is the limited information disclosure to customers related to products or other business activities. Customers need more information to meet their curiosity towards the products and services offered, but also how the activities of the company affect the lives of stakeholders, and moreover their conformity with sharia. Abdullah et al. (2015) suggest that in the halal industry, the commitment of the company to provide good and services, which in line with sharia is indeed crucial. Jaffer et al. (2010) reveal that "...Compliance should cover all aspects of the operation, including the Takaful model adopted, product offerings, surplus sharing, and fee structures, Islamic investments, contract wording, and marketing material.." (p.19).

\section{Customer Satisfaction and Islamic Insurance}

Customer satisfaction (CS) may be one of the challenges most noticed by an organization (Zairi, 2000) because CS influences business continuity. Knowing what makes a satisfied customer can help the company improve the quality of products and services (Zineldin, 2000). Customer satisfaction is an emotional reaction to the difference between what customers expect and what they receive (Zineldin, 2000). Cronin et al. (cited in Ranaweera and Prabhu (2003) defines CS as "... evaluation of emotion, reflecting the degree to which the customer believes the service provider evokes positive feelings" (p.374). Many researches state the benefits got by the company when it has satisfied customers, such as becoming loyal and less sensitive to 
price, buying other products of company, less influenced by other competitors, and improving the corporate image (Zineldin, 2000), and increasing the profitability of the company (Aydin \& Ozer, 2005). Customer satisfaction becomes essential to make consumers tied to the company by fulfilling customer's need and expectation. For takaful operator, customer satisfaction will attract not only Muslim customer but also Non-Muslim customer when the satisfied customer share their good experience with other people (Ishak, 2017). According to Shaladdin, Mokhtar, \& Zawawi (2018), the customer will be satisfied if the takaful operator can give the good service quality to them. Therefore all systems, procedures, and guidelines of a company directed to serve the best needs of the customer (Zairi, 2000). Asher (1989) states that the company can do several ways to measure CS, including personal interviews, focus group, customer day, telephone surveys, paper surveys, and mystery calls. The goal is to identify what matters are important for consumer and how much the consumer's belief that the company is capable of fulfilling it.

Customer satisfaction and quality improvement should always be the focus of the company (Aydin \& Ozer, 2005). CS can be measured with some indicators (Ranaweera \& Prabhu, 2003; Hansemark \& Albinsson, 2004; Aydin \& Ozer, 2005 and Ganiyu, Uche, \& Elizabeth, 2012), namely experience, expectation, and satisfaction. Experience performs the feeling of customers in doing the transaction with the company. The basic of relationship is mutual benefit, which will result in more frequent contacts and dialogue. Expectation indicates the suitability of the product or service available with customer expectations. The expectation can be built by communicating a reasonable picture of the performance of the company's product to give the clear assumption of what to expect when consuming or buying those products (Rahim \& Amin, 2011). The last aspect is satisfaction. It indicates the overall satisfaction level of products and services offered.

\section{Customer loyalty and Islamic Insurance}

Bowen and Chen (2001) mention that consumer loyalty (CL) definition can be seen from three perspectives, namely behavioral; attitudinal; and composite measurements. The behavioral measurements indicate the consistent and repetitive purchase behavior. Attitudinal perspective measures the emotional and psychological attachment inherent in loyalty using attitudinal data. Composite model measures loyalty on specific indicators such as customers' product preferences, the propensity of brand-switching, frequency of purchase, recency of purchase, and total amount of purchase. Because the customer is the heart of business success, the company need to offer a high-quality product to ensure the customers are satisfied with their product (Abdullah et al., 2015). Honesty in conveying the benefits and defects of the products when introducing them to the customer will satisfy the customer (Rahim \& Amin, 2011).

Customer satisfaction is very important to enhance customer loyalty that in the long term can affect the performance, profitability, and existence of the company in the industrial market (Shank, Hill, \& Stang, 2013). Other benefits of having loyal customer are increasing profits due to increasing sales and reducing operating costs because they will re-purchase the same product and even other additional products regardless of 
price (Reichheld and Sasser, cited in Bowen \& Chen, 2001). Takaful industry, which offers similar services and products, views customer loyalty as an important element in maintaining business continuity (Shaladdin et al., 2018).

Customer loyalty can be performed with these three measurements (Bowen and Chen, 2001; Aydin and Ozer, 2005; Ganiyu et al., 2012); first, repurchase intention, is measured by the degree of customer desire to continue purchasing new products. Customer will do repurchase after having good experience with the service provider and comparing with its competitor (Zairi, 2000). Second, resistance to switching other products and services offered by the competitors and third, willingness to recommend products and services to other parties.

\section{Corporate Governance and Customer Satisfaction}

The customer becomes an important part of the company because it can affect the survival of the company. The companies must be able to meet the expectations of consumers from all sides, such as the good system of marketing management, finance, and reporting, including sharia compliance. Corporate governance becomes attention because of its important role in the economic health of corporations and society. Corporate governance promotes ethical behavior to maintain the interest of key stakeholder groups (Arjoon, 2005). Implementation of corporate governance principles is beneficial to the company in protecting the interest of stakeholders, especially customer, as an effort to improve the reputation and trust of the takaful industry in the market. CG will contribute to the management of the company to produce good performance, including meeting the needs of customers in term of information, report, product, and services provided by takaful companies. It hopefully will increase customer confidence and satisfaction to the company, including the need to conduct halal transactions. Hamid (2011) reveals that customer satisfaction can be used as a performance indicator in the services industry.

Husin and Rahman (2016) find that knowledge and perceived behavioral control influenced the intention of customers to participate in takaful. These two variables can be enhanced by providing information as a basis for the customer to consider the product and services of Islamic insurance companies. Lee and Shakir (2011) who examine the attitude of Islamic banking in Pakistan, find that Islamic banks customer strongly consider the sharia compliance, and will switch to another bank if they knew the sharia violation on that bank. Lee and Shakir (2011) also state that the customer will consider other factors such as convenience, funds security, and advanced technology. According to Ishak (2017), trust is one of the determinants of customer satisfaction in Takaful because it indicates the confidence of customer to the service of Takaful. Therefore, the company must implement effective corporate governance which can be achieved by adopting a set of principles and best practices (Arjoon, 2005). Based on the explanation above, the hypothesis is:

\section{$\boldsymbol{H}_{1}$ : Corporate governance has positive influence on customer satisfaction.}




\section{Corporate Governance and Customer Loyalty}

Implementation of CG principles includes transparency, accountability, responsibility, independence, fairness, and Sharia compliance principles will be examined to find their relationship with customer loyalty. The services of the company such as the accessibility of the required information, good services, good financial performance, the transparency of funds management and Shariah compliance of company's activities will become a consideration for customers to determine their loyalty. Those can improve the corporate image of takaful companies and influence people to use their services. A good corporate image because of the implementation of good corporate governance will increase the customer's loyalty in takaful. Loyal customers have impact on less cost to serve because of their knowledge about the company (Bowen \& Chen, 2001). Using five principles of CG with the addition of sharia compliance principle, both El-Junusi (2012) and Wardayati (2011) state that sharia governance influenced customer's trust in Islamic banking in Indonesia. Al-Qudah (2012) finds that corporate governance positively influenced customer commitment and trust in Jordan Medium- Large enterprises. Therefore, the hypothesis is:

$\boldsymbol{H}_{2}$ : Corporate governance has positive influence on customer loyalty.

\section{Customer Satisfaction and Customer Loyalty}

Customer satisfaction on a product or service greatly affects customer's repurchase intention to the same product (Mohsan et al., 2011). In the financial industry, customer satisfaction is an important indicator to improve customer loyalty. Having a loyal customer is very profitable for the company because of the certainty of demand owned by the company's products. Products and services that meet the needs of customers will increase customer satisfaction and encourage the loyalty of the customer. In the insurance industry, the key to customer satisfaction lies in the good relationship between consumers and insurance companies as a provider of products and services (Bowen \& Chen, 2001). Mohsan et al. (2011) collect data from customers of banking industry in Pakistan and found that customer satisfaction was positively correlated with customer loyalty. The most important factor for enhancing loyalty is customer satisfaction (Aydin \& Ozer, 2005). Ganiyu et al. (2012) also support the finding that customer satisfaction and loyalty have a relationship. Based on the explanation above, the formulated hypothesis is:

$\boldsymbol{H}_{3}$ : Customer satisfaction has positive influence on customer loyalty.

\section{Research Method}

Figure 1 shows the theoretical framework of the study. This paper uses a questionnaire for getting primary data from respondents. A purposive sampling technique is used to distribute the questionnaire among the customer of Islamic insurance companies in Yogyakarta, Indonesia, who have been customers for at least one year. In designing the 
questionnaires, the study relies on them from the previous researches with selfmodification to adjust with Islamic insurance respondent. The questionnaires divided into three sections. The first section contains corporate governance principles that consist of transparency, accountability, accountability, responsibility, independence, fairness, and sharia compliance (El-Junusi, 2012; Wardayati, 2011). The second section will be asked about customer satisfaction, that consists of experience, expectation, and satisfaction (Aydin \& Ozer, 2005; Hansemark \& Albinsson, 2004). The third section is customer loyalty that measuring with the repurchase, recommendation, and commitment (Aydin \& Ozer, 2005; Bowen \& Chen, 2001; Ganiyu et al., 2012).

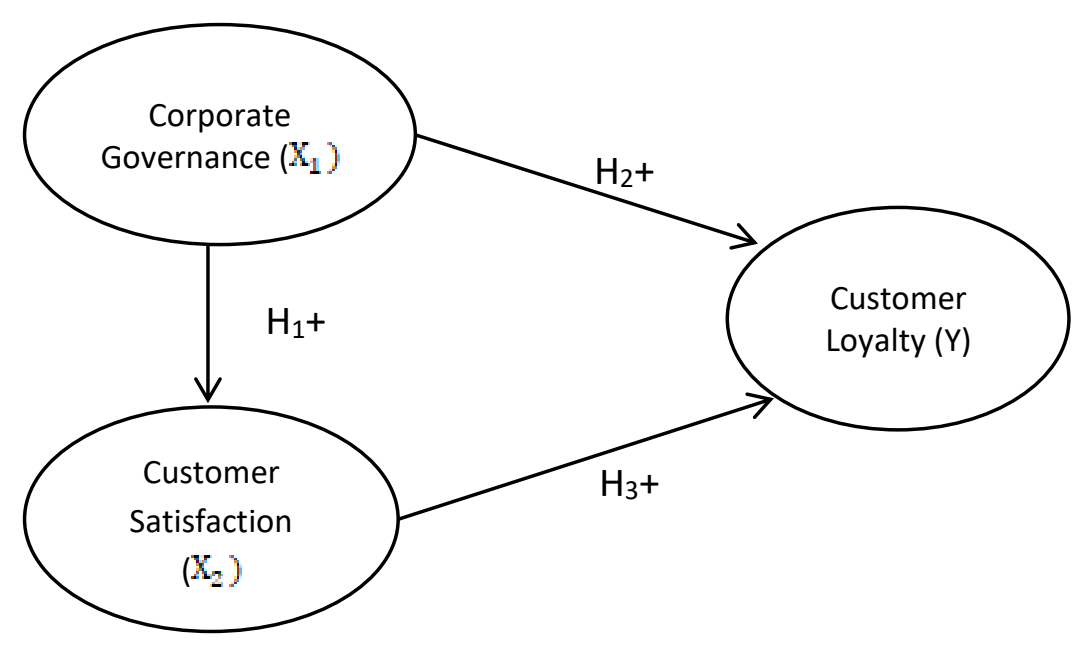

Figure 1 Theoretical Framework of the Study

The scale in the questionnaire has five points Likert scale with responses ranging from strongly disagree to strongly agree.The validity of the scale is measured using Pearson's Product Moment Correlation method, and reliability of the scales is measured using Cronbach's alpha. The hypotheses are analyzed using simple and multiple regression of SPSS 22.

\section{Result and Discussion}

\section{Statistical Result}

There are 115 questionnaires distributed to the respondents, and from 100 questionnaires (87\%) that can be collected, 97 questionnaires are valid and can be processed or $84 \%$ of response rate. The variables have fulfilled the validity and reliability test. The score of Cronbach's alpha of reliability test for corporate governance, customer satisfaction, and customers loyalty are $0.924,0.806$, and 0.866 . 
The Impact of Corporate Governance on Customer Satisfaction and Loyalty of Islamic Insurance...

Tabel 1. Demographics of Respondents

\begin{tabular}{|c|c|c|}
\hline Gender & Frequency & Percentages (\%) \\
\hline Male & 43 & 45 \\
\hline Female & 54 & 56 \\
\hline Total & 97 & 100 \\
\hline Age & Frequency & Percentages (\%) \\
\hline $17-25$ year & 33 & 35 \\
\hline $26-35$ year & 24 & 25 \\
\hline $36-45$ year & 19 & 20 \\
\hline$>45$ year & 19 & 20 \\
\hline Total & 97 & 100 \\
\hline Education & Frequency & Percentages (\%) \\
\hline Senior High School & 11 & 11 \\
\hline Diploma & 21 & 22 \\
\hline Bachelor & 48 & 49 \\
\hline Master & 11 & 11 \\
\hline Above Master & 6 & 7 \\
\hline Total & 97 & 100 \\
\hline Profession & Frequency & Percentages (\%) \\
\hline Government Employees & 27 & 28 \\
\hline Private Employees & 39 & 40 \\
\hline Self Employed & 10 & 10 \\
\hline Others & 21 & 22 \\
\hline Total & 97 & 100 \\
\hline Income/month & Frequency & Percentages (\%) \\
\hline$<$ Rp. 1.000 .000 & 9 & 9 \\
\hline Rp. $1.000 .000-$ Rp. 5.000 .000 & 48 & 49 \\
\hline Rp. $5.000 .000-$ Rp. 10.000 .000 & 18 & 19 \\
\hline > Rp. 10.000 .000 & 22 & 23 \\
\hline Total & 97 & 100 \\
\hline $\begin{array}{l}\text { Duration becoming Islamic insurance } \\
\text { customer }\end{array}$ & Frequency & Percentages (\%) \\
\hline$<1$ year & 10 & 11 \\
\hline $1-5$ year & 48 & 49 \\
\hline$>5$ year & 39 & 40 \\
\hline Total & 97 & 100 \\
\hline $\begin{array}{l}\text { The reason for being customer of Islamic } \\
\text { insurance }\end{array}$ & Frequency & Percentages (\%) \\
\hline Recommendation from other costumers & 22 & 23 \\
\hline Promotion & 19 & 20 \\
\hline Islamic insurance agen & 14 & 14 \\
\hline Sharia compliance & 25 & 26 \\
\hline Others & 17 & 17 \\
\hline Total & 97 & 100 \\
\hline
\end{tabular}

Table 1 provides the demographics of respondents of the Islamic insurance industry. It is clear from Table 1 that $56 \%$ of the respondents are females, and $45 \%$ are males. The ages of respondents are majority below 35 years old (60\%), and more than $48 \%$ of respondents held a bachelor degree. There is $40 \%$ of respondents who work as private, and $28 \%$ of them are government employees. Most respondents with the percentage of 
$49 \%$ have income between one million rupiahs until five million rupiahs. It can also be observed that the majority of the respondent (49\%) have used Islamic insurance between 1-5 years and $38 \%$ of respondents more than five years of experience. The duration is important to investigate the customer satisfaction and loyalty because they have enough experience to feel the services by the company. The interesting information is also found that $26 \%$ of respondents choose Islamic insurance because of its sharia compliance. Like one of the Islamic financial institutions, Islamic Insurance will also be highlighted related to its accordance with sharia principles. While $23 \%$ of respondents get a recommendation from others, and $20 \%$ consider the promotion in choosing Islamic Insurance.

Table 2 presents the result of descriptive statistics. The mean value of corporate governance (CG) is 102.6, and the standard deviation is 10.503, the mean value of customer satisfaction (CS) and customer loyalty (CL) are 25.85, and 27.21 with a standard deviation of each variable is 3.327 and 3.699 .

Table 2 Descriptive Statistics Analysis

\begin{tabular}{lcccccc}
\hline & N & Range & Min. & Max. & Mean & Std. Deviation \\
\hline Corporate governance & 97 & 92 & 39 & 131 & 102,60 & 10,503 \\
Customer satisfaction & 97 & 25 & 9 & 34 & 25,85 & 3,327 \\
Customer loyalty & 97 & 21 & 14 & 35 & 27,21 & 3,699 \\
\hline
\end{tabular}

Table 3 provides the two regression result for the hypotheses above. Simple regression is used to examine the relationship between corporate governance and customer satisfaction. The coefficient of determination (adjusted R square) is 0.341 or $34,1 \%$, which means the dependent variable (customer satisfaction) can be explained by the corporate governance variables for $34.1 \%$, while the remaining $65.9 \%$ is explained by other variables not examined. The significant value of $0.000<0.05$ means that corporate governance influences customer satisfaction positively and significantly; therefore, $\mathrm{H} 1$ is accepted.

Table 3 Regression Results

\begin{tabular}{lrr}
\hline $\mathrm{H}_{1}$ & Simple Regression & \\
\hline Variable & B Value & Sig. Value \\
Corporate Governance & 0.197 & 0.00 \\
F-test & & 0.000 \\
Adj R Square & & 0.341 \\
& & Multiple Regression \\
$\mathrm{H}_{2}$ and $\mathrm{H}_{3}$ & B Value & Sig. Value \\
Variables & 0.102 & 0.003 \\
Corporate Governance & 0.47 & 0.000 \\
Customer Satisfaction & & 0.000 \\
F-test & & 0.473 \\
Adj R Square & & \\
\hline
\end{tabular}


Multiple regression is used to answer hypothesis 2 and 3 . The adjusted R square is 0.473 or $47,3 \%$, which means the independent variables (corporate governance and customer satisfaction) can explain the dependent variable (customer loyalty) at amount of $47,3 \%$ while the rest of $52,7 \%$ is explained by other variables not examined. Table 3 also indicates that all independent variables in the model influence significantly to customer loyalty. The significant value of corporate governance (0.003) and customer satisfaction (0.000) are smaller than $p$-value of 0.05 , mean that each of the variables affects customer loyalty. Therefore, $\mathrm{H} 2$ and $\mathrm{H} 3$ are accepted.

\section{Discussion}

This study finds that corporate governance has positive influence on customer satisfaction in Islamic insurance companies in Indonesia. Corporate governance is one of the solutions to improve takaful performance because it promotes fairness, transparency, and accountability to build relationships and trust with both internal and external parties (Arjoon, 2005). The company will take into account the interest of all stakeholders, including customers, to ensure that they feel satisfied in do relation with the company. This study supports the previous research by Ishak (2017), who argue that trust from customers built through good communication and process of Takaful's operation will lead to customer satisfaction.

The result of hypothesis two indicates the significant positive influence of corporate governance toward customer loyalty. The implementation of CG on the company is expected to support the good performance of the company in term of transparency, accountability, responsibility, and fairness. This study supports the previous researches by El-Junusi (2012), Wardayati (2011) and Al-Qudah (2012). Good CG will direct all the sources of the company to act in order to achieve the company's objectives by ensuring the fairness to all stakeholders. These results also support Arjoon's (2005) statement that effective corporate governance based on integrity and trust will increase competitive advantage so that it affects not only to customer loyalty but also employee loyalty.

The study also reveals that customer satisfaction has positive relationship with customer loyalty in Islamic insurance in Indonesia. The finding is in line with the research done by Hansemark \& Albinsson (2004), Aydin \& Ozer (2005), Mohsan et al. (2011), and Ganiyu et al. (2012). Different result is found by Bowen and Chen (2001), who examined the attributes that increase customer loyalty in the hospitality industry and the study found that the relationship between customer satisfaction and customer loyalty is not linear. It means that in a certain level of satisfaction, loyalty is an increase, but once is reduced, loyalty can decrease drastically.

The role of consumers is important for the company. Customer satisfaction and loyalty provide added value to the company because it can affect the performance, profitability and existence of the company in the industrial market (Shank et al., 2013; Mohsan et al., 2011). The satisfied customer becomes an indicator of profit and competitiveness of the company in the future and will reflect the survival of the company (Ganiyu et al., 2012). 
This is because customer satisfaction arises from their experience during build relationship with the company. Good or bad experience will determine whether the consumer will re-purchase the same product or services of the company or buy other products offered by the company in the future. Arjoon (2005) states that customer satisfaction becomes a key factor whether the customer will be a loyal customer or not. Loyal customers will have such characteristics as re-purchasing the company's products and services, believing that the company's products and services are better than competitors, not actively looking for an alternative product from competitors, and buying other products or services the company offers. With the creation of an optimal level of customer satisfaction encourages the creation of loyalty in the minds of customers who feel satisfied earlier.

Further, the development of Takaful industry should be encouraged as one of the investment tools by shariah. The challenges facing takaful now are to enhance competitiveness and fulfill shariah requirement to maintain customer and takaful operator fairly (Jaffer et al., 2010). The demographic data (Table 1) indicates that the majority of consumers choose takaful because of its conformity with sharia. Takaful company according to its characteristics then should be able to show the compliance of its business activities with shariah principle.

\section{Conclusion}

The main purpose of corporate governance in the insurance industry is to enhance the trust of the policyholder and other stakeholders. The research finds that corporate governance has a significant positive relationship to customer satisfaction and customer loyalty in the Islamic insurance company in Indonesia. Another finding also suggests that customer satisfaction influences significantly to customer loyalty. Islamic insurance companies should not only rely on accordance with sharia, but the quality of products and services and good performance must always be maintained. This is because Muslim investors also consider other aspects than just sharia compliance when they choose a financial investment. Implementation of corporate governance as a way for the company to achieve its goals and provide the best for its customer in order to create customer satisfaction and customer loyalty.

This result of study provides implications for Islamic insurance companies to give more attention to the implementation of corporate governance in order to build a long-term relationship between management and customer. Takaful industry also should keep customer satisfaction because it will influence customer loyalty to be able to compete with the conventional counterpart. As an Islamic financial institution, Shariah compliance with good performance will enhance the customer's confidence to be always engaged with Islamic insurance services. A large market for Islamic insurance not only increases profitability and maintains the company's survival, but also facilitates people who want to invest in Islamic business. Customers who participate in this research and have takaful account majority have high education level and relatively still young (refer to Table 1). Those give a good picture for the development of takaful in the 
The Impact of Corporate Governance on Customer Satisfaction and Loyalty of Islamic Insurance...

future that young educated people have intention to takaful. Although they can also be critical when the products and services offered do not give them satisfaction. Takaful industry must improve its performance to create customer satisfaction and loyalty.

There are several limitations related to this research. First, the respondents of this research are customers of Islamic insurance, and it can not be generalized to other customers of IFIs. Second, this study only examines at the impact of CG variables and does not explore other factors, and third, the research uses the principle of CG as a variable independent. Based on those limitations, the paper suggests some recommendations for further research. The next research needs to expand the type of customers, such as Islamic banks, or even compare with the customer of conventional financial institution to get more comprehensive results. The other factors such as quality services or other items of CG such as organs of CG, it can be considered to be variables that are explored more in seeking their relationship with customer satisfaction and customer loyalty.

\section{References}

Abdullah, J. bin, Hamali, J. H., \& Abdullah, F. (2015). Succes Strategies in Islamic Marketing Mix. International Journal of Business and Society, 16(3), 480-499. https://doi.org/10.33736/ijbs.581.2015

Al-Qudah, M. Y. (2012). The Effect of Corporate Governance on Customer Relationship Quality and Marketing Performance. Unpublished Thesis. Middle East University.

Ali, A. M. H. (2011). Telaah Umum Tentang Asuransi Syariah di Indonesia (The General Discussion of Islamic Insurance in Indonesia). Al-Iqthisad, 3(1), 49-64. Retrieved from http://journal.uinjkt.ac.id/index.php/iqtishad/article/view/2496

Arjoon, S. (2005). Corporate Governance : An Ethical Perspective. Journal of Business Ethics, 61(4), 343-352. https://doi.org/10.1007/s10551-005-7888-5

Asher, M. (1989). Measuring Customer Satisfaction. The TQM Magazine, 1(2), 92-97. https://doi.org/10.1108/eum0000000002995

Aydin, S., \& Ozer, G. (2005). The Analysis of Antecedents of Customer Loyalty in the Turkish Mobile Telecommunication Market. European Journal of Marketing, 39(7/8), 910-925. https://doi.org/10.1108/03090560510601833

Bowen, J. T., \& Chen, S. L. (2001). The Relationship Between Customer Loyalty and Customer Satisfaction. International Journal of Contemporary Hospitality Management, 13(5), 213-217. https://doi.org/10.1108/09596110110395893

El-Junusi, R. (2012). Implementasi Shariah Governance Serta Implikasinya Terhadap Reputasi dan Kepercayaan Bank Syariah. Al-Tahrir: Jurnal Pemikiran Islam, 12(1), $91-$ 115. https://doi.org/10.21154/al-tahrir.v12i1.48

Ganiyu, R. A., Uche, I. I. kechukwu, \& Elizabeth, A. O. (2012). Is Customer Satisfaction an Indicator of Customer Loyalty? Australian Journal of Business and Management Research, 2(7), 14-20.

Hamid, F. S. (2011). Measuring Service Quality in The Takaful Industry. SEGi Review, 4(1), 118-124. Retrieved from http://www.onlinereview.segi.edu.my/pdf/vol4-no1art11.pdf

Hansemark, O. C., \& Albinsson, M. (2004). Customer Satisfaction and Retention : The Experiences of Individual Employees. Managing Service Quality: An International Journal, 
The Impact of Corporate Governance on Customer Satisfaction and Loyalty of Islamic Insurance...

14(1), 40-57. https://doi.org/10.1108/09604520410513668

Hasan, Z. (2009). Corporate Governance : Western and Islamic Perspectives. International Review of Business Research Paper, 5(1), 277-293. Retrieved from http://citeseerx.ist.psu.edu/viewdoc/download?doi=10.1.1.483.641\&rep=rep1\&type= pdf

Husin, M. M., \& Rahman, A. A. (2016). Do Muslims Intend to Participate In Islamic Insurance? Analysis From Theory of Planned Behaviour. Journal of Islamic Accounting and Business Research, 7(1), 42-58. https://doi.org/10.1108/jiabr-03-2014-0012

Ishak, N. H. I. (2017). Concept Paper: Customer Satisfaction in Malaysian Takaful Industry. International Journal of Academic Research in Business and Social Sciences, 7(3), 380-391.

Retrieved from http://hrmars.com/hrmars_papers/Concept_Paper_Customer_Satisfaction_in_Malay $\underline{\text { sian Takaful_Industry.pdf }}$

Jaffer, S., Ismail, F., Noor, J., \& Unwin, L. (2010). Takaful (Islamic Insurance ): Concept, Challenges, and Opportunities. Retrieved from http://mbri.ac.ir/userfiles/file/Islamic\%20Banking/مقالات20/Takaful/takaful\% 20 (islamic-insurance) $\% 20$ concept $\% 20$ challenges $\% 20$ and $\% 20$ opportunities.pdf

Janjua, P. Z., \& Akmal, M. (2014). A Comparative Analysis of Customers 'Satisfaction for Conventional and Islamic Insurance Companies in Pakistan. International Journal of Economics and Finance, 6(4), 36-50. https://doi.org/10.5539/ijef.v6n4p36

Kamarulzaman, Y., \& Madun, A. (2013). Marketing Islamic Banking Products : Malaysian Perspective. Business Strategy Series, 14(2/3), 60-66. https://doi.org/10.1108/17515631311325114

Lee, K., \& Shakir, U. (2011). Customers ' Attitude Toward Islamic Banking in Pakistan. International Journal of Islamic and Middle Eastern Finance and Management, 4(2), 131-145. https://doi.org/10.1108/17538391111144524

Mohsan, F., Nawaz, M. M., Khan, M. S., Shaukat, Z., \& Aslam, N. (2011). Impact of Customer Satisfaction on Customer Loyalty and Intentions to Switch: Evidence from Banking Sector of Pakistan. International Journal of Business and Social Science, 2(16), 263270. Retrieved from http://ijbssnet.com/journals/Vol 2 No 16 September 2011/30.pdf

Rahim, F. A., \& Amin, H. (2011). Determinant of Islamic Insurance Acceptance: An Empirical Analysis. International Journal of Business and Society, 12(2), 37-54. Retrieved from https://s3.amazonaws.com/academia.edu.documents/31419863/Vol12No2paper3.pd $\underline{\text { ? AWSAccessKeyId=AKIAIWOWYYGZ2Y53UL3A\&Expires=1558423067\&Signatu }}$ re=0UlaZigL5NX6eWzoRerwrUZQ8kQ\%3D\&response-contentdisposition=inline $\% 3 \mathrm{~B} \% 20$ filename $\% 3$ DDETERMINANTS OF ISLAMIC INSUR ANCEACCEPTA.pdf

Ranaweera, C., \& Prabhu, J. (2003). The Influence of Satisfaction, Trust and Switching Barriers on Customer Retention in a Continuous Purchasing Setting. International Journal of Service Industry Management, 14(4), 374-395. https://doi.org/10.1108/09564230310489231

Redhika, R., \& Mahalli, K. (2014). Analisis Potensi dan Kendala Pengembangan Asuransi Syariah di Kota Medan. (Analysis of Potential and Constraint of Islamic Insurance Development in Medan). Jurnal Ekonomi dan Keuangan, 2(5), 323-335. Retrieved from https://jurnal.usu.ac.id/index.php/edk/article/download/11693/5046

Shaladdin, Z. F. M., Mokhtar, M. Z., \& Zawawi, N. H. M. (2018). Determinants of Customer Satisfaction in Takaful (Islamic Insurance) Services in Malaysia. Jurnal Pengurusan, 54(December), 1-12. Retrieved from 
The Impact of Corporate Governance on Customer Satisfaction and Loyalty of Islamic Insurance...

http://ejournal.ukm.my/pengurusan/article/view/30085

Shank, T., Hill, R. P., \& Stang, J. (2013). Do Investors Benefit From Good Corporate Governance? Corporate Governance: The International Journal of Business in Society, 13(4), 384-396. https://doi.org/10.1108/cg-03-2010-0027

Tahir, I., \& Brimble, M. (2011). Islamic Investment Behaviour. International Journal of Islamic and Middle Eastern Finance and Management, 4(2), 116-130. https://doi.org/10.1108/17538391111144515

Wardayati, S. M. (2011). Implikasi Shariah Governance Terhadap Reputasi dan Kepercayaan Bank Syariah (The Implication of Sharia Governance Toward Reputation and Trust in Islamic Bank). Walisongo, 19(1), 1-24. https://doi.org/10.21580/ws.2011.19.1.210

Zairi, L. S. (2014). Takaful A Solidarity Based Channel. "The Role of Islamic Finance in Sustainable Development" Roundtable Discussion with UN Committee. Retrieved from https://sustainabledevelopment.un.org/content/documents/10284Lotfizairipresentati on.pdf

Zairi, M. (2000). Managing Customer Satisfaction : A Best Practice Perspectiv. TQM Magazine, 12(6), 389-394. https://doi.org/10.1108/09544780010351670

Zineldin, M. (2000). Total Relationship Management (TRM) and Total Quality Management (TQM). Managerial Auditing Jounal, 15(1/2), 20-28. https://doi.org/10.1108/02686900010304399

\section{Article in Website:}

Karim Consulting. (2017). Islamic Insurance Outlook 2017. http://karimconsulting.com/wpcontent/uploads/2016/11/Outlook-Asuransi-Syariah finall uploadweb.pdf accessed at 15 March 2018.

KNKG. (2010). Pedoman Good Corporate Governance Perusahaan Asuransi dan Perusabaan Reasuransi Indonesia (The Guidance of Good Corporate Governance of Insurance Company and ReInsurance Company in Indonesia). Komite Nasional Kebijakan Governance. http://www.knkg-indonesia.org accessed at 15 March 2018.

OJK. (2018). Laporan Perkembangan Keuangan Syariah Indonesia 2017 (The Development of Islamic Finance in Indonesia of 2017). https://www.ojk.go.id/id/berita-dankegiatan/publikasi/Documents/Pages/Laporan-Perkembangan-Keuangan-Syariah2017/Laporan \%20Perkembangan \%20Keuangan $\% 20$ Syariah $\% 20$ Indonesia $\% 20$ (LPKSI \%202017\%20\%20(final).pdf accessed 15 March 2018

OJK. (2016). POJK Nomor 73/POJK.05/ 2016 tentang Tata Kelola Perusahaan Yang Baik Bagi Perusahaan Perasuransian (Good Corporate Governance for Insurance Companies). Otoritas Jasa Keuangan. Indonesia. https://www.ojk.go.id/id accessed 15 March 2018 